\title{
Geospatial mapping of health risk from trace metal(loid)s in the soil at an abandoned painting factory
}

\author{
Andrijana Miletić ${ }^{1} \mathbb{D}$, Aleksandra Savićc $^{2}$, Latinka Slavković-Beškoski² ${ }^{\circledR}$,

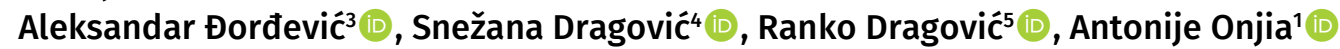 \\ ${ }^{1}$ Faculty of Technology and Metallurgy, University of Belgrade, Karnegijeva 4, 11120 Belgrade, Serbia \\ ${ }^{2}$ Anahem Laboratory, Mocartova 10, 11160 Belgrade, Serbia \\ ${ }^{3}$ Faculty of Agriculture, University of Belgrade, Nemanjina 6, 11080 Belgrade, Serbia \\ ${ }^{4}$ Vinča Institute of Nuclear Sciences - National Institute of the Republic of Serbia, University of Belgrade, P.O. Box 522, Belgrade, Serbia \\ ${ }^{5}$ University of Niš, Faculty of Sciences and Mathematics, Department of Geography, Višegradska 33, 18000 Niš, Serbia
}

\author{
Keywords: \\ Heavy metals, \\ GIS, \\ ELCR, \\ Hazard quotient.
}

\begin{abstract}
A survey was made to analyze the geostatistical (GIS) distribution of the health risk of toxic trace metal(loid)s in the industrial soil located in the facility of an abandoned paints manufacturing company. A total of eighty surface soil samples were collected, and their concentrations determined. The mean concentration values of the elements were $7.8 ; 2.7 ; 55 ; 49$; $0.21 ; 56 ; 114$; and $239 \mathrm{mg} / \mathrm{kg}$ for As, $\mathrm{Cd}, \mathrm{Cr}, \mathrm{Cu}, \mathrm{Hg}, \mathrm{Ni}, \mathrm{Pb}$, and $\mathrm{Zn}$, respectively. There was no non-carcinogenic health risk from the soil samples for adults, but it was hazardous soil for children with the excess lifetime cancer risk (ELCR) values exceeding the reference value of 10-4 for all studied samples. Most contributing toxic metal(loid)s to non-carcinogenic risk were $\mathrm{Cr}$ and As, whereas $\mathrm{Pb}$ and As were most responsible for cancer risk. Geospatial mapping of the hazard index (HI) and ELCR localized different hotspots seriously polluted by toxic metal(loid)s, which pose a significant risk in the area. These hotspots coincided with the evidence of transport-related activities and spillage of chemicals in the past. This GIS spatial distribution study could be a valuable aid in remediation planning.
\end{abstract}

\section{Introduction}

Rapid technological development has caused a ceasing of the operation of a large number of manufacturing companies. Many of these companies have been located in an urban area, so their land could be used for other purposes, such as housing, parks, commerce, etc. Anyhow, soil quality should be investigated to figure out whether pollution from former industrial activities has taken place (Wcisło et al., 2002).

Numerous studies have dealt with multivariate analysis of toxic trace metal(loid)s pollution of soil using principal component and hierarchical cluster analyses (PCA, HCA) (Slavković et al., 2004; Dragović et al., 2013; Dragović et al., 2018; Onjia, 2016; Škrbić et al., 2018; Tanić et al., 2018; Egbueri et al., 2020). These studies were aimed to recognize the soil contamination pattern and pinpoint the potential pollution sources. Also, ecological risk indices have been commonly evaluated to get a better insight into soil pollution (Dragović et al., 2014; Çulha, et al., 2017; Relić et al., 2019; Radomirović et al., 2020; Lukić et al., 2020; Minkina et al., 2020).

On the other hand, the essential part of the soil contamination investigation is to estimate the potential health risk originated from toxic trace metal(loid)s in the soil (Loredo et al., 2003; Gržetić and Ghariani, 2008). Health risk assessment (HRA), as a process used to estimate health effects of toxic trace metal(loid)s humans residing around the abandoned factory, should be carried out (EPA, 2013). HRA consist of 
four necessary steps: identification of hazard, exposure assessment, dose-response assessment, and risk characterization (EPA, 2013). Hazard identification, as the first step, aims to analyze toxic elements present at a given location, including their soil contents and spatial distribution. The second step, i.e. exposure assessment, determines the frequency, duration, and intensity of human exposures to a toxic element. This is usually carried out by estimating the chronic daily intake (CDI) value for specific toxic element through ingestion, inhalation and dermal contact routes by children and adults. Children and adults are different in terms of both mental and physiological aspects (EPA, 2011). Dose-response assessment uses the reference dose (RfD) and cancer slope factor (CSF) to evaluate the non-carcinogenic and carcinogenic toxicity due to exposure to a toxic element, respectively. The last step comprising the risk characterization integrates all previously gathered data to quantify risks (EPA, 2011). The non-carcinogenic health risk may be assessed using the risk quotient $(\mathrm{RQ})$ for each element and sample. In parallel, the excess lifetime cancer risk (ELCR) parameter is used to estimate carcinogenic risk.

Having in mind that the potential health risk of the soil pollution may be non-uniformly distributed over the study area, a geostatistical evaluation (Petrović et al., 2018; Trujillo-González et al., 2019) is needed. A spatial mapping using a geostatistical information system (GIS) enables meaningful information about soil pollution and the economic cost in soil sampling and analysis since excessive sampling and testing are not necessary. The GIS kriging interpolation method may successfully describe and predict the spatial distribution of toxic trace metal(loid)s concentrations of a non-sampled area.

This study deals with the trace elements contamination of the soil in the facility of an abandoned painting factory (Duga doo, Belgrade). The pollution by toxic trace metal(loid)s of this area has been studied recently (Radomirović et al., 2020), but no health risk assessment was made. The aim of this study is to identify pollution hotspots and to identify anthropogenic sources of the toxic meta(loid)s contamination of soil by geospatial mapping of HRA results.

\section{Materials and methods}

\subsection{Study area, sample handling and preparation}

The study area of approximately 11 ha is located in the Duga a.d. facility in Belgrade (Serbia). A total of 80 composite samples of surface soil were taken in duplicate. The distribution of the sampling points is shown in Figure 1. A soil core sampler was used for sampling. A composite sample consisting of 5 individual samples was transferred into a plastic jar and kept cool until analysis. The samples were air-dried in the laboratory, pulverized, and sieved ( $2 \mathrm{~mm}$ pores). Afterwards, the samples were subjected to microwave-assisted digestion as described elsewhere (Radomirović et al., 2020).

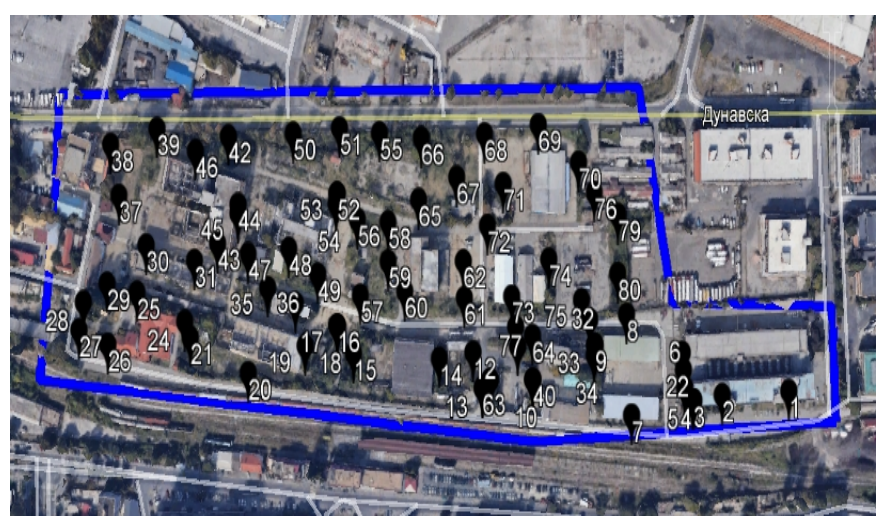

Figure 1. The study area and distribution of sampling sites.

\subsection{Instrumental measurement and $Q A / Q C$ control}

A concentrated mixture of $\mathrm{HNO} 3, \mathrm{HCl}$, and $\mathrm{H} 2 \mathrm{O} 2$ was used for pseudo-total metal(loid)s digestion. The obtained solution with the dissolved metal(loid)s were analyzed by an Atomic Absorption Spectrometry (AAS) using a Perkin-Elmer model Analyst 100 instrument, which is equipped with a deuterium background correction lamp and hollow-cathode/electrodeless discharge lamps. Apart from the measurements of the concentrations of $\mathrm{Cr}, \mathrm{Cd}, \mathrm{Pb}, \mathrm{Ni}, \mathrm{Zn}, \mathrm{Cu}$, the concentration of As and $\mathrm{Hg}$ were determined using a model MHS-15 cold vapour accessory (Perkin-Elmer).

Quality assurance and quality control (QA/QC) was done by analyzing blanks and duplicates, as well as a NIST Certified Reference Material SRM 2711a (Montana II Soil). All recoveries obtained were between $83-104 \%$, and the relative standard deviation was within $12 \%$.

\subsection{Health risk assessment}

CDI for the different potential exposure routes for toxic metal(loid)s in soil may be estimated using the following Equations (EPA, 2013)

$$
\begin{aligned}
& C D I_{\text {ingest }}=(C \cdot \operatorname{lng} R \cdot E F \cdot E D \cdot C F) /(B W \cdot A T) \\
& C D I_{\text {inhal }}=(C \cdot \operatorname{Inh} R \cdot E F \cdot E D \cdot C F) /(P E F \cdot B W \cdot A T) \\
& C D I_{\text {dermal }}=(C \cdot S A \cdot S L \cdot A B F \cdot E F \cdot E D \cdot C F) /(B W \cdot A T)
\end{aligned}
$$


Table 1. HRA exposure parameters for the ingestion, inhalation and dermal contact exposure pathways (EPA 2013).

\begin{tabular}{lccc}
\hline \multicolumn{1}{c}{ Parameter } & Unit & Adults & Children \\
\hline Concentration of heavy metal (C) & $\mathrm{mg} / \mathrm{kg}$ & & \\
Ingestion rate (IngR) & $\mathrm{mg} / \mathrm{d}$ & 100 & 200 \\
Exposure frequency (EF) & $\mathrm{d} /$ year & 350 & 350 \\
Exposure duration (ED) & years & 24 & 6 \\
Bodyweight (BW) & $\mathrm{kg}$ & 70 & 15 \\
Average time (AT) & $\mathrm{days}$ & 8760 & 2190 \\
Inhalation rate (InhR) & $\mathrm{m}^{3} / \mathrm{d}$ & 15 & 10 \\
Particulate emission factor (PEF) & $\mathrm{m}^{3} / \mathrm{kg}$ & $1.36 \cdot 10^{9}$ & $1.36 \cdot 10^{9}$ \\
Skin surface area (SA) & $\mathrm{cm}^{2}$ & 5700 & 2800 \\
Soil adherence factor (SL) & $\mathrm{mg} / \mathrm{cm}^{2}$ & 0.07 & 0.2 \\
Dermal absorption factor (ABF) & $\mathrm{none}$ & 0.01 & 0.001 \\
Conversion factor (CF) & $\mathrm{kg} / \mathrm{mg}^{-6}$ & $10^{-6}$ & $10^{-6}$ \\
\hline
\end{tabular}

where the meanings and values of the exposure parameters in Eqs. (1) - (3) were given in Table 1.

Hazard quotient (HQ) characterizes non-carcinogenic risk. It is a unitless number calculated as the ratio of CDI and $\mathrm{RfD}$ of an individual toxic element (Eq. 4)

$$
H Q=C D I / R f D
$$

Hazard Index (HI) represents the summation of all individual HQs (Eq. 5)

$$
H I=H Q_{\text {ingest }}+H Q_{\text {inhal }}+H Q_{\text {dermal }}
$$

where $\mathrm{HQ}_{\text {ingest }}, \mathrm{HQ}_{\text {inhal }}$, and $\mathrm{HQ}_{\text {dermal }}$ are risks contributions through ingestion, inhalation and dermal contact routes.

Carcinogenic risk estimated as excess lifetime cancer risk (ELCR) is defined as the probability of an individual to develop cancer over a lifetime due to exposure to potential carcinogens. The mathematical representation of this parameter is given in Eq. (6).
Table 2. RfD (mg/kg-day) and CSF ((mg/kg-day $\left.)^{-1}\right)$ for the different toxic metal(loid)s and expose pathways.

\begin{tabular}{ccccccc}
\hline & RfD $_{\text {ingest }}$ & RfD $_{\text {inhal }}$ & RfD $_{\text {dermal }}$ & CSF ingest & CSF $_{\text {inhale }}$ & CSF $_{\text {dermal }}$ \\
\hline As & $3.00 \mathrm{E}-04$ & $1.23 \mathrm{E}-04$ & $1.23 \mathrm{E}-04$ & $1.50 \mathrm{E}+00$ & $4.30 \mathrm{E}-03$ & $3.66 \mathrm{E}+00$ \\
$\mathrm{Cd}$ & $1.00 \mathrm{E}-03$ & $1.00 \mathrm{E}-05$ & $1.00 \mathrm{E}-05$ & - & $6.30 \mathrm{E}+00$ & - \\
$\mathrm{Cr}$ & $3.00 \mathrm{E}-03$ & $2.86 \mathrm{E}-05$ & $6.00 \mathrm{E}-05$ & $5.00 \mathrm{E}-01$ & $4.20 \mathrm{E}+01$ & $2.00 \mathrm{E}+01$ \\
$\mathrm{Cu}$ & $4.00 \mathrm{E}-02$ & $4.02 \mathrm{E}-03$ & $1.20 \mathrm{E}-02$ & - & - & - \\
$\mathrm{Hg}$ & $3.00 \mathrm{E}-04$ & $8.57 \mathrm{E}-05$ & $2.10 \mathrm{E}-05$ & - & - & - \\
$\mathrm{Ni}$ & $2.00 \mathrm{E}-02$ & $2.06 \mathrm{E}-02$ & $5.40 \mathrm{E}-03$ & - & - & - \\
$\mathrm{Pb}$ & $3.50 \mathrm{E}-03$ & $3.52 \mathrm{E}-03$ & $5.25 \mathrm{E}-04$ & $8.50 \mathrm{E}-03$ & $4.20 \mathrm{E}-02$ & - \\
$\mathrm{Zn}$ & $3.00 \mathrm{E}-01$ & $3.00 \mathrm{E}-01$ & $6.00 \mathrm{E}-02$ & - & - & - \\
\hline \multicolumn{7}{c}{$\mathrm{ELCR}=\mathrm{CDI} \cdot \mathrm{CSF}$}
\end{tabular}

The total ELCR is a unitless probability calculated from the contribution of each carcinogenic substance for all expose routes according to the following equation:

$$
E L C R=E L C R_{\text {ingest }}+E L C R_{\text {inhal }}+E L C R_{\text {dermal }}
$$

The health risks of toxic metal(loid)s in the soil are estimated using CSF and RfD values (EPA, 2011), as shown in Table 2 .

\subsection{Geostatistical data analysis}

GIS maps of the trace metal(loid)s in the soil were created using Surfer software (Golden Software Inc.). Due to the number of buildings and infrastructure installations, the sampling points were unevenly distributed. Hence, ordinary kriging was used to develop the GIS spatial interpolation maps of health risks in the area.

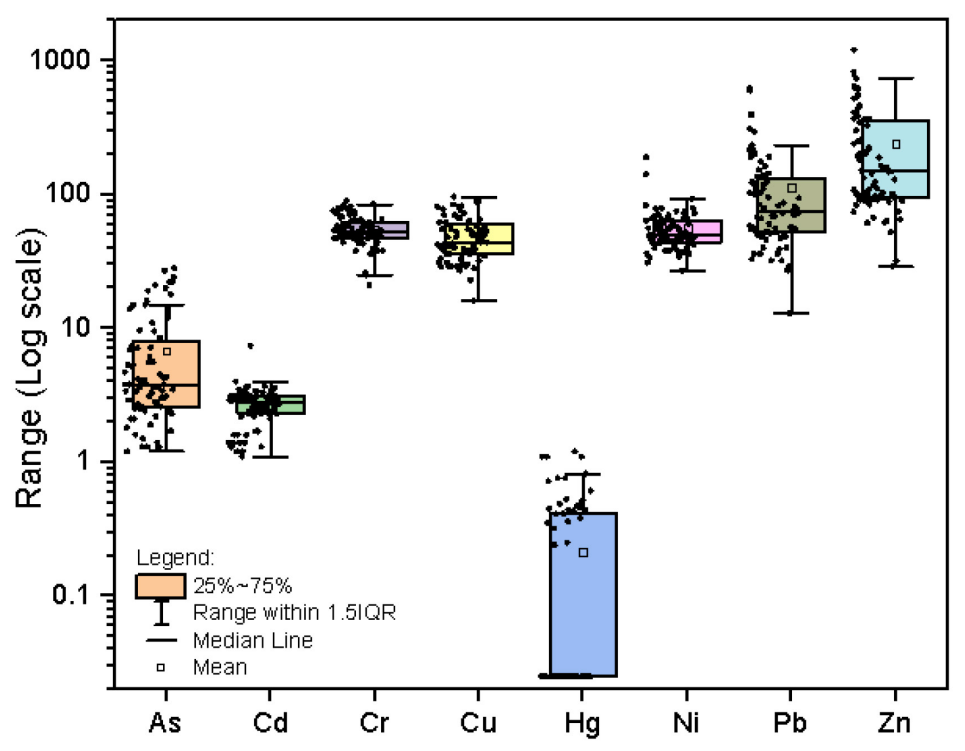

Figure 2. Trace metal(loid)s distribution in the soil ( $\mathrm{mg} / \mathrm{kg}$ ). 


\section{Results and discussion}

\subsection{Trace metal(loid)s distribution}

Figure 2 depicts the distribution of the eight trace metal(loid)s in the studied soil from an abandoned painting manufacturing site. The results indicate that the concentrations of the studied metal(loid)s varied significantly and decreased in the following order: $\mathrm{Zn}>\mathrm{Pb}>\mathrm{Ni}>\mathrm{Cr}>\mathrm{Cu}>\mathrm{As}>$ $\mathrm{Cd}>\mathrm{Hg}$. The average concentration values $(\mathrm{mg} / \mathrm{kg})$ are as follows: As (7.8); Cd (2.7); Cr (55); Cu (49); Hg (0.21); Ni (56); $\mathrm{Pb}$ (114); and $\mathrm{Zn}$ (239). These average metal(loid)s concentrations exceeded the target limits ( $\mathrm{mg} / \mathrm{kg}$ ) for $\mathrm{Ni}(35), \mathrm{Cu}(36)$, $\mathrm{Cd}(0.8)$ and $\mathrm{Pb}(85)$ (Official Gazette of the Republic of Serbia, 2018).

\subsection{Health risk assessment}

\subsubsection{Non-carcinogenic risk}

Table 3 presents non-carcinogenic risks estimated based on CDI and RfD values for ingestion, inhalation and dermal contact pathways, presented in terms of HQs AND HIs for children and adults.

There will be no obvious non-carcinogenic human health risk when $H Q$ and $H I$ values are $\leq 1$. However, there are some samples in which the concentrations of $\mathrm{As}$, and $\mathrm{Pb}$ in particular, are very high. Consequently, HQ and HI for these samples exceed the limit value of one for children. The risk of $\mathrm{Pb}$ in polluted soil area for children is due to the oral intake route. No individual non-carcinogenic human health risk was estimated in the area for adults. These risk assessment results show that the most significant concern for both populations is mainly attributed to $\mathrm{Pb}$. The total minimum, mean, and maximum HI values were $0.08 ; 0.19 ; 0.47$; and 0.38 ; 1.10; 2.92; for adults and children, respectively. The total HI for children greater the one scenario was found in $45 \%$ of the analyzed soil samples. The oral ingestion route is a major contributor to the total non-carcinogenic health risk.

\subsubsection{Carcinogenic risk}

The carcinogenic HRA was based on the following metal(loid)s: As; $\mathrm{Cd}$; $\mathrm{Cr}$; and $\mathrm{Pb}$. Acceptable cancer risk is in the range of $10^{-6}$ to $10^{-4}$ (EPA, 2013). The individual and total $\Sigma$ ELCR for children and adults are estimated from the contribution of each carcinogenic metal(loid)s in the soil for all the expose routes using Eqs. (6) and (7). The results of the individual ELCR values are given in Table 4 . The individual ELCR was found to be in the range of $4.3 \cdot 10^{-5}$ to $2.1 \cdot 10^{-4}$ and $2.0 \cdot 10^{-4}$ to $1.1 \cdot 10^{-3}$ for adults and children, respectively. The ELCR values are mostly influenced by the ingestion pathway. In general, children are more at risk than adults due to the presence of toxic metal(loid)s this study area. The total $\Sigma$ ELCR results ranged from $4.3 \cdot 10^{-5}$ to $1.2 \cdot 10^{-4}$ and $2.0 \cdot 10^{-4}$ to $1.1 \cdot 10^{-3}$ for adults and children, respectively. Additionally, $70 \%$ and 100 $\%$ of the total $\Sigma E L C R$ results for adults and children, respectively, exceed the threshold value for cancer risk of $10^{-4}$. It

Table 3. HQs and HIs for the ingestion, inhalation and dermal contact pathways for (a) adults and (c) children.

\begin{tabular}{|c|c|c|c|c|c|c|c|c|}
\hline $\mathrm{HQ}$ or HI & As & $\mathrm{Cd}$ & $\mathrm{Cr}$ & $\mathrm{Cu}$ & $\mathrm{Hg}$ & $\mathrm{Ni}$ & $\mathrm{Pb}$ & $\mathrm{Zn}$ \\
\hline $\mathrm{HQ}_{\text {a,ing mean }}$ & 0.0310 & 0.0037 & 0.0252 & 0.0017 & 0.0010 & 0.0038 & 0.0446 & 0.0011 \\
\hline $\mathrm{HQ}_{\mathrm{a}, \text { ing max }}$ & 0.1279 & 0.0101 & 0.0406 & 0.0033 & 0.0055 & 0.0129 & 0.2411 & 0.0055 \\
\hline $\mathrm{HQ}_{\mathrm{a}, \text { ing min }}$ & 0.0055 & 0.0015 & 0.0096 & 0.0005 & 0.0001 & 0.0018 & 0.0051 & 0.0001 \\
\hline$H Q_{a, \text { inh mean }}$ & 0.0000 & 0.0000 & 0.0000 & 0.0000 & 0.0000 & 0.0000 & 0.0000 & 0.0000 \\
\hline $\mathrm{HQ}_{\mathrm{a}, \mathrm{inh} \max }$ & 0.0000 & 0.0000 & 0.0000 & 0.0000 & 0.0000 & 0.0000 & 0.0000 & 0.0000 \\
\hline $\mathrm{HQ}_{\mathrm{a}, \text { inh min }}$ & 0.0000 & 0.0000 & 0.0000 & 0.0000 & 0.0000 & 0.0000 & 0.0000 & 0.0000 \\
\hline $\mathrm{HQ}_{\mathrm{a} \text {,derm mean }}$ & 0.0030 & 0.0147 & 0.0503 & 0.0002 & 0.0006 & 0.0006 & 0.0119 & 0.0002 \\
\hline $\mathrm{HQ}_{\mathrm{a}, \text { derm max }}$ & 0.0124 & 0.0404 & 0.0811 & 0.0004 & 0.0031 & 0.0019 & 0.0641 & 0.0011 \\
\hline$H Q_{a, \text { derm min }}$ & 0.0005 & 0.0060 & 0.0191 & 0.0001 & 0.0001 & 0.0003 & 0.0014 & 0.0000 \\
\hline $\mathrm{Hl}_{\mathrm{a} \text {, mean }}$ & 0.0340 & 0.0184 & 0.0755 & 0.0019 & 0.0015 & 0.0044 & 0.0564 & 0.0013 \\
\hline $\mathrm{HI}_{\mathrm{a}, \max }$ & 0.1403 & 0.0506 & 0.1217 & 0.0037 & 0.0086 & 0.0149 & 0.3052 & 0.0066 \\
\hline $\mathrm{HI}_{\mathrm{a}, \min }$ & 0.0060 & 0.0075 & 0.0287 & 0.0006 & 0.0002 & 0.0021 & 0.0064 & 0.0002 \\
\hline$H Q_{c, \text { ing mean }}$ & 0.2895 & 0.0344 & 0.2353 & 0.0157 & 0.0090 & 0.0358 & 0.4158 & 0.0102 \\
\hline $\mathrm{HQ}_{\text {c,ing } \max }$ & 1.1933 & 0.0946 & 0.3793 & 0.0307 & 0.0511 & 0.1208 & 2.2502 & 0.0511 \\
\hline $\mathrm{HQ}_{\mathrm{c} \text {,ing min }}$ & 0.0511 & 0.0141 & 0.0895 & 0.0051 & 0.0011 & 0.0173 & 0.0475 & 0.0012 \\
\hline $\mathrm{HQ}_{c, \text { inh mean }}$ & 0.0000 & 0.0000 & 0.0000 & 0.0000 & 0.0000 & 0.0000 & 0.0000 & 0.0000 \\
\hline$H Q_{c, \text { inh max }}$ & 0.0000 & 0.0000 & 0.0000 & 0.0000 & 0.0000 & 0.0000 & 0.0000 & 0.0000 \\
\hline $\mathrm{HQ}_{c, \text { inh min }}$ & 0.0000 & 0.0000 & 0.0000 & 0.0000 & 0.0000 & 0.0000 & 0.0000 & 0.0000 \\
\hline$H Q_{c, \text { derm mean }}$ & 0.0020 & 0.0096 & 0.0329 & 0.0001 & 0.0004 & 0.0004 & 0.0078 & 0.0001 \\
\hline$H Q_{c, \text { derm max }}$ & 0.0081 & 0.0265 & 0.0531 & 0.0003 & 0.0020 & 0.0013 & 0.0420 & 0.0007 \\
\hline$H Q_{c, \text { derm min }}$ & 0.0003 & 0.0039 & 0.0125 & 0.0000 & 0.0000 & 0.0002 & 0.0009 & 0.0000 \\
\hline $\mathrm{HI}_{\mathrm{c} \text {, mean }}$ & 0.2915 & 0.0441 & 0.2682 & 0.0158 & 0.0094 & 0.0362 & 0.4236 & 0.0103 \\
\hline $\mathrm{HI}_{c, \max }$ & 1.2015 & 0.1211 & 0.4324 & 0.0310 & 0.0532 & 0.1221 & 2.2922 & 0.0518 \\
\hline $\mathrm{HI}_{\mathrm{c}, \min }$ & 0.0515 & 0.0180 & 0.1020 & 0.0052 & 0.0011 & 0.0174 & 0.0484 & 0.0013 \\
\hline
\end{tabular}


Table 4. ELCR for the ingestion, inhalation and dermal contact pathways for adults and children

\begin{tabular}{|c|c|c|c|c|}
\hline ELCR & As & $C d$ & $\mathrm{Cr}$ & $\mathrm{Pb}$ \\
\hline ELCR $_{a, \text { ing mean }}$ & $1.40 \mathrm{E}-05$ & $0.00 \mathrm{E}+00$ & $3.78 \mathrm{E}-05$ & $1.33 \mathrm{E}-06$ \\
\hline $\mathrm{ELCR}_{\mathrm{a}, \mathrm{ing} \max }$ & $5.75 \mathrm{E}-05$ & $0.00 E+00$ & $6.10 \mathrm{E}-05$ & 7.17E-06 \\
\hline$E L C R_{a, \text { ing min }}$ & $2.47 \mathrm{E}-06$ & $0.00 \mathrm{E}+00$ & $1.44 \mathrm{E}-05$ & $1.51 \mathrm{E}-07$ \\
\hline $\mathrm{ELCR}_{\mathrm{a}, \text { inh mean }}$ & 4.41E-18 & $2.56 \mathrm{E}-15$ & $3.50 \mathrm{E}-13$ & $7.22 \mathrm{E}-16$ \\
\hline $\mathrm{ELCR}_{\mathrm{a}, \mathrm{inh} \max }$ & $1.82 \mathrm{E}-17$ & $7.04 \mathrm{E}-15$ & $5.65 \mathrm{E}-13$ & $3.91 \mathrm{E}-15$ \\
\hline $\mathrm{ELCR}_{\mathrm{a}, \text { inh min }}$ & $7.80 \mathrm{E}-19$ & $1.05 E-15$ & $1.33 \mathrm{E}-13$ & $8.25 \mathrm{E}-17$ \\
\hline $\mathrm{ELCR}_{\mathrm{a}, \mathrm{derm} \text { mean }}$ & $1.36 \mathrm{E}-06$ & $0.00 E+00$ & $6.03 \mathrm{E}-05$ & $0.00 E+00$ \\
\hline $\mathrm{ELCR}_{\mathrm{a}, \mathrm{derm} \max }$ & $5.60 \mathrm{E}-06$ & $0.00 \mathrm{E}+00$ & $9.73 \mathrm{E}-05$ & $0.00 \mathrm{E}+00$ \\
\hline $\mathrm{ELCR}_{\mathrm{a}, \mathrm{derm} \text { min }}$ & $2.40 \mathrm{E}-07$ & $0.00 \mathrm{E}+00$ & $2.30 \mathrm{E}-05$ & $0.00 \mathrm{E}+00$ \\
\hline$\Sigma E C R_{a}$, mean & $1.53 \mathrm{E}-05$ & $2.56 \mathrm{E}-15$ & $9.82 \mathrm{E}-05$ & $1.33 \mathrm{E}-06$ \\
\hline$\Sigma \mathrm{ELCR}_{\mathrm{a}}$ max & $6.31 \mathrm{E}-05$ & 7.04E-15 & $1.58 \mathrm{E}-04$ & 7.17E-06 \\
\hline$\sum E \mathrm{CR}_{\mathrm{a}, \mathrm{min}}$ & $2.71 \mathrm{E}-06$ & $1.05 E-15$ & $3.73 \mathrm{E}-05$ & $1.51 \mathrm{E}-07$ \\
\hline $\mathrm{ELCR}_{\text {c,ing mean }}$ & $1.30 \mathrm{E}-04$ & $0.00 \mathrm{E}+00$ & $3.53 \mathrm{E}-04$ & $1.24 \mathrm{E}-05$ \\
\hline ELCR $_{c, \text { ing } \max }$ & $5.37 \mathrm{E}-04$ & $0.00 \mathrm{E}+00$ & $5.69 \mathrm{E}-04$ & $6.69 \mathrm{E}-05$ \\
\hline $\mathrm{ELCR}_{c, \text { ing min }}$ & $2.30 \mathrm{E}-05$ & $0.00 \mathrm{E}+00$ & $1.34 \mathrm{E}-04$ & $1.41 \mathrm{E}-06$ \\
\hline $\mathrm{ELCR}_{c, \text { inh mean }}$ & $1.37 \mathrm{E}-17$ & $7.98 \mathrm{E}-15$ & $1.09 \mathrm{E}-12$ & $2.25 \mathrm{E}-15$ \\
\hline $\mathrm{ELCR}_{c, \text { inh } \max }$ & $5.66 \mathrm{E}-17$ & $2.19 \mathrm{E}-14$ & $1.76 \mathrm{E}-12$ & $1.22 \mathrm{E}-14$ \\
\hline $\mathrm{ELCR}_{c, \text { inh min }}$ & $2.43 \mathrm{E}-18$ & $3.26 \mathrm{E}-15$ & $4.15 \mathrm{E}-13$ & $2.57 \mathrm{E}-16$ \\
\hline $\mathrm{ELCR}_{c, \text { derm mean }}$ & $8.90 \mathrm{E}-07$ & $0.00 \mathrm{E}+00$ & $3.95 \mathrm{E}-05$ & $0.00 \mathrm{E}+00$ \\
\hline $\mathrm{ELCR}_{\mathrm{c}, \text { derm max }}$ & $3.67 \mathrm{E}-06$ & $0.00 \mathrm{E}+00$ & $6.37 \mathrm{E}-05$ & $0.00 \mathrm{E}+00$ \\
\hline $\mathrm{ELCR}_{c, \text { derm min }}$ & $1.57 \mathrm{E}-07$ & $0.00 \mathrm{E}+00$ & $1.50 \mathrm{E}-05$ & $0.00 \mathrm{E}+00$ \\
\hline$\Sigma E C R_{c, \text { mean }}$ & $1.31 \mathrm{E}-04$ & $7.98 \mathrm{E}-15$ & $3.92 \mathrm{E}-04$ & $1.24 \mathrm{E}-05$ \\
\hline$\sum \mathrm{ELCR}_{\mathrm{c}, \max }$ & $5.41 \mathrm{E}-04$ & $2.19 \mathrm{E}-14$ & $6.33 \mathrm{E}-04$ & $6.69 \mathrm{E}-05$ \\
\hline$\sum \mathrm{ELCR}_{c, \min }$ & $2.32 \mathrm{E}-05$ & $3.26 \mathrm{E}-15$ & $1.49 \mathrm{E}-04$ & 1.41E-06 \\
\hline
\end{tabular}

means the studied area should be avoided before the remediation measures are undertaken.

\subsection{Geostatistical mapping}

The geospatial mapping of toxic trace metal(loid)s in soil was made using a GIS approach. Firstly, the element concentrations were interpolated with the ordinary kriging technique. Then, the GIS-based maps of non-carcinogenic and carcinogenic risk indices were compared. The obtained GIS maps are presented in Figure 3. In general, the darker red colour area in the filled contour maps indicate the highest risk, while the green coloured area suggested low risks. A few red hotspots of high HIs and ELCRs were identified in Figure 3. A quite different distribution of hotspots for non-carcinogenic and carcinogenic risks was obtained.

These maps of HIs show no exceedance of a level of one for adults in the study area and reveal the sub-area with unacceptable high risk for children (HI>1). The ELCR results locate the highest risk at the one hotspot for adults and several hotspots for children. These hotspots were located in a different part of the area. Moreover, the geospatial pattern reveals the sub-area with severe HI and ELCR hotspots for children. Lead, followed by As, are the most responsible metal(loid)s for non-carcinogenic risk. On the other hand, ELCR results indicate $\mathrm{Cr}$ and $\mathrm{As}$ as the most detrimental metal(loid)s that pose the cancer risk in the area.
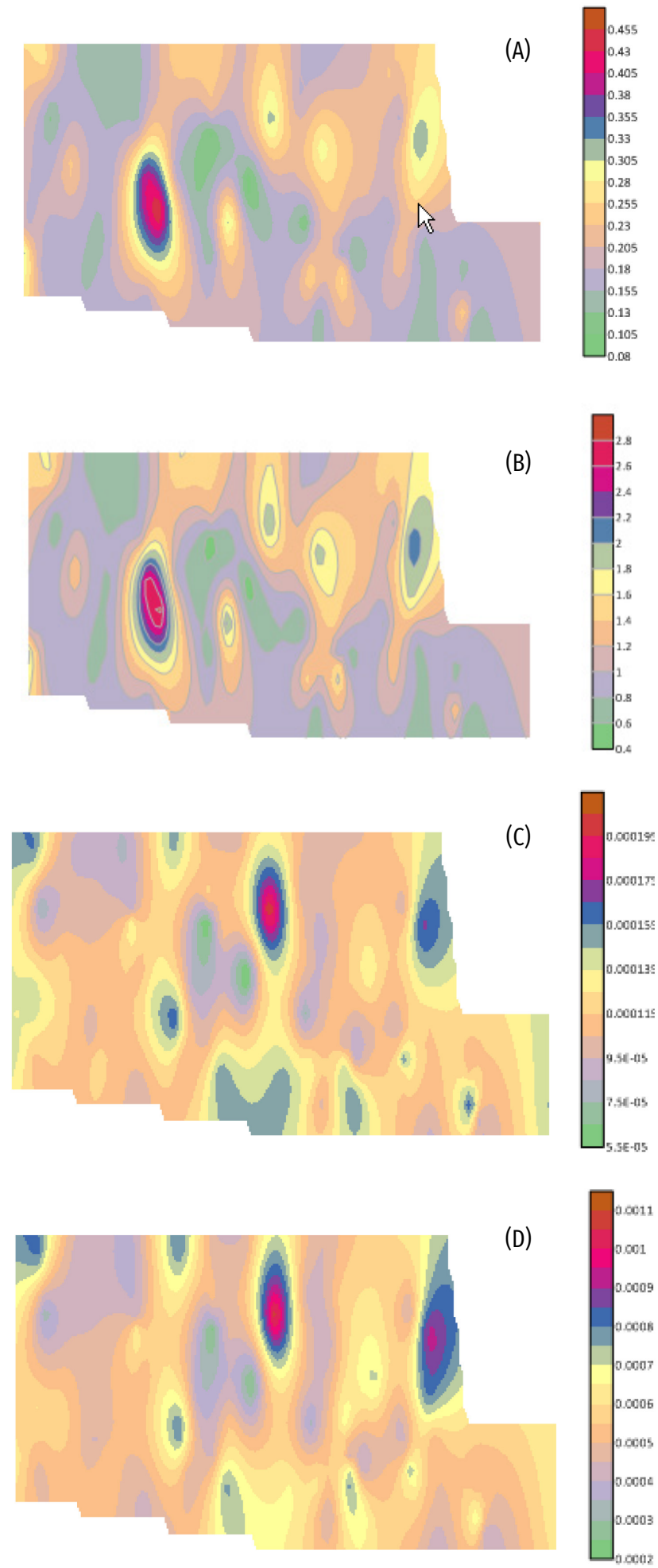

Figure 3. Geospatial distribution maps of HI and ELCR in the soil. (A) HIa; (B) HIC; (C) LELCRa; (D) LELCRC.

A reasonable association was readily displayed between these hotspots and risks with the former industrial activities. The hotspot with the highest HI values was located in the area of the abandoned car mechanic workshop, where vehicle-related activities had been concentrated. The main 
ELCR hotspot is placed in the previous chemical waste storage area. The second ELCR hotspot coincided with the area used for the manipulation with the raw materials in the past. These findings were harmonized with the previous investigation of the same location (Radomirović et al., 2020)

In this work, it seems reasonable to conclude that $\mathrm{Pb}, \mathrm{Cr}$ and As constitute an anthropogenic component of the soil contamination, which is associated with specific activities in the past. Apart from this, the other toxic metal(loid)s appear to originate from the soil parent materials that are mostly the alluvial river deposits from the Danube River bank terrace (Mihailović et al., 2015).

\section{Conclusion}

The results obtained in the analysis of soil from an abandoned painting manufacturing site show that the eight studied toxic trace metal(loid)s varied significantly and decreased in the following order: $\mathrm{Zn}>\mathrm{Pb}>\mathrm{Ni}>\mathrm{Cr}>\mathrm{Cu}>\mathrm{As}>$ $\mathrm{Cd}>\mathrm{Hg}$. The average metal(loid)s concentrations in soil showed higher than target limits for $\mathrm{Ni}, \mathrm{Cu}, \mathrm{Cd}$ and $\mathrm{Pb}$.

Geospatial mapping of health risk due to toxic trace metal(loid)s content in soil indicated similar spatial distribution patterns for adults and children. However, the spatial pattern between carcinogenic and non-carcinogenic risk differs significantly. Moreover, children are more vulnerable to the carcinogenic and non-carcinogenic risks, with $45 \%$ of the studied soil samples exceeded reference value one of hazard index and $100 \%$ of the total $\Sigma E L C R$ values exceeded the cancer threshold risk of $10^{-4}$. It means that children should avoid this area before the remediation measures are undertaken. The primary pathway to exposure to cancer and noncancer risks is ingestion.

In conclusion, GIS mapping of HRA results may effectively identify hotspots and indicate anthropogenic sources of the toxic metal(loid)s contamination of soil. These findings may help in the subsequent remediation of the polluted soil.

\section{Acknowledgement}

This work was supported by the Ministry of Education, Science and Technological Development of the Republic of Serbia (Contract No. 451-03-68/2020-14/200135).

\section{ORCID iDs}

Andrijana Miletić (D) https://orcid.org/0000-0002-6310-5235 Aleksandra Savić (D) https://orcid.org/0000-0002-1210-5497 Latinka Slavković Beškoski (D) https://orcid.org/0000-0002-8650-5020 Aleksandar Đorđević (iD https://orcid.org/0000-0002-2989-6483 Snežana Dragović (D) https://orcid.org/0000-0003-0566-0182 Ranko Dragović (ID https://orcid.org/0000-0002-4662-7808 Antonije Onjia (D) https://orcid.org/0000-0002-5694-7960

\section{References}

Çulha, S.T., Çulha, M., Karayücel, İ., Çelik, M.Y., Işler, Y., 2017. Heavy metals in Mytilus galloprovincialis, suspended particulate matter and sediment from offshore submerged longline system, Black Sea. International Journal of Environmental Science and Technology, 14(2), 385-396.

Dragović, S., Kovačević, M., Bajat, B., Onjia, A., 2018. Support vector machines for classification of soils according to geographic origin based on their radionuclide content. Serbian Journal of Geosciences, 4(1), 15-26.

Dragović, R., Gajić, B., Dragović, S., Đorđević, M., Đorđević, M., Mihailović, N., Onjia A., 2014. Assessment of the impact of geographical factors on the spatial distribution of heavy metals in soils around the steel production facility in Smederevo (Serbia). J. Clean. Prod. 84, 550-562. Dragović, S., Ćujić, M., Slavković-Beškoski, L., Gajić, B., Bajat, B., Kilibarda, M., Onjia, A., 2013. Trace element distribution in surface soils from a coal burning power production area: A case study from the largest power plant site in Serbia. Catena 104, 288-296.

Gržetić, I., Ghariani, R.H.A., 2008. Potential health risk assessment for soil heavy metal contamination in the central zone of Belgrade (Serbia). J. Serb. Chem. Soc. 73(8-9), 923-934.

Egbueri, J.C., Ukah, B.U., Ubido, O.E., Unigwe, C.O., 2020. A chemometric approach to source apportionment, ecological and health risk assessment of heavy metals in industrial soils from southwestern Nigeria. Int. J. Environ. Anal. Chem. 1-19.

EPA, 2002. Supplemental Guidance for Developing Soil Screening Levels for Superfund Sites. Office of Solid Waste and Emergency Response. DCOSWER 9355.4-24. US EPA, Washington.

EPA, 2011. Exposure Factors Handbook (EFH), US EPA, Washington.

EPA, 2013. Regional Screening Levels (RSLs), Risk Assessment, US EPA. Washington.

Loredo, J., Ordonez, A., Charlesworth, S., De-Miguel, E., 2003. Influence of industry on the geochemical urban environment of Mieres (Spain) and associated health risk. Environ. Geochem. Health 25(3), 307-323.

Lukić, J., Đurkić, T., Jovanović, L., Aleksić, G., Onjia, A., 2020. Total petroleum hydrocarbons distribution and health risk assessment of soil in the Niš railway junction. Ecologica 27(100), 597-604. 
Mihailović, A., Budinski-Petković, L., Popov, S., Ninkov, J., Vasin, J., Ralević, N. M., Vučinić Vasić, M., 2015. Spatial distribution of metals in urban soil of Novi Sad, Serbia, GIS based approach. J. Geochem. Explor. 150, 104-114.

Minkina, T., Konstantinova, E., Bauer, T., Mandzhieva, S., Sushkova, S., Chaplygin, V., Burachevskaya, M., Nazarenko, O., Kizilkaya, R., Gülser, C., Maksimov, A., 2020. Environmental and human health risk assessment of potentially toxic elements in soils around the largest coal-fired power station in Southern Russia. Environmental Geochemistry and Health, 1-16.

Official Gazette of the Republic of Serbia, 2018. Rulebook on limit values of pollutants, harmful and hazardous substances in soil, No. 30/2018.

Onjia, A., 2016. Chemometric approach to the experiment optimization and data evaluation in analytical chemistry. University of Belgrade, Faculty of Technology and Metallurgy, Belgrade.

Petrović, J., Dragović, R., Gajić, B., Đorđević, M., Dragović, S., 2018. Depth distribution of ${ }^{137} \mathrm{Cs}$ in soils from special nature reserve Banat sands, Serbia and assessment of doses to non-human biota. Serbian Journal of Geosciences 4(1), 1-14.

Radomirović, M., Ćirović, Ž., Maksin, D., Bakić, T., Lukić, J., Stanković, S., Onjia, A., 2020. Ecological Risk Assessment of Heavy Metals in the Soil at a Former Painting Industry Facility. Front. Environ. Sci. 8, 560415.

Relić, D., Sakan, S., Andelković, I., Popović, A., Đorđević, D., 2019. Pollution and health risk assessments of potentially toxic elements in soil and sediment samples in a petrochemical industry and surrounding area. Molecules 24, 2139.

Škrbić, B., Buljovčić, M., Jovanović, G., Antić, I., 2018. Seasonal, spatial variations and risk assessment of heavy elements in street dust from Novi Sad, Serbia. Chemosphere 205, 452-462.

Slavković, L., Škrbić, B., Miljević, N., Onjia, A., 2004. Principal component analysis of trace elements in industrial soils. Environ. Chem. Lett. 2(2), 105-108.

Tanić, M., Onjia, A., Janković Mandić, L., Ćujić, M., Dinić, D., Dragović, S., 2018. Human health risk assessment due to natural radionuclides in soil affected by coal combustion: A case study from the surroundings of the largest thermoelectric power plant in Serbia. Ecologica 25, 5-11.

Trujillo-González, J. M., Torres-Mora, M. A., Jiménez-Ballesta, R., Zhang, J., 2019. Land-use-dependent spatial varia- tion and exposure risk of heavy metals in road-deposited sediment in Villavicencio, Colombia. Environmental geochemistry and health 41(2), 667-679.

Wcisło, E., Ioven, D., Kucharski, R., Szdzuj, J., 2002. Human health risk assessment case study: an abandoned metal smelter site in Poland. Chemosphere 47(5), 507-515. 